\title{
Review \\ Challenges and opportunities for revitalising smallholder irrigation schemes in South Africa
}

\author{
M Fanadzo ${ }^{1 *}$ and B Ncube ${ }^{1}$ \\ 'Department of Agriculture, Faculty of Applied Sciences, Cape Peninsula University of Technology, Private Bag X8, Wellington 7654, South Africa
}

\begin{abstract}
South Africa is classified as a water-scarce country, and depends on agriculture for food production. The irrigation sector is the largest consumer of water in the country, accounting for about $62 \%$ of water utilisation, but also losing $30-40 \%$. Given the threat of drought and climate change, efficient irrigation systems have become a necessity, especially in the smallholder farming sector where most losses occur. Smallholder irrigation schemes (SIS) were developed to improve rural livelihoods through sustainable food production for food security and poverty alleviation, but these development objectives remain largely unfulfilled. The objectives of this review were to assess challenges facing SIS and explore opportunities for revitalising the schemes. The focus was on government policy and strategies to support smallholder farmers. A review of government policy showed that although the needs and interests of smallholder farmers are high on the national agenda, there is insufficient financial support to the sector, suggesting that smallholder agriculture is not really seen as a potential driver of the economy. The core focus of the government on repairing irrigation infrastructure while neglecting the soft components relating to capacity building has partly been blamed for the failure of SIS in South Africa. Capacity building is one of the missing links in smallholder irrigation development and many failures have been attributed to lack of adequately trained farmers and extension staff, particularly in irrigation water management. Land tenure insecurity has been singled out as a major institutional challenge leading to poor performance of irrigation schemes. The diversity of schemes means that different kinds of interventions are needed to respond to varying farmers' needs, resources and agricultural contexts. These findings point to the need to balance the soft and hard components of the irrigation schemes for sustainability. It is therefore evident that the government needs to review its priorities in revitalisation of SIS. Land tenure policies allowing increased access to arable land need to be developed urgently, together with the promotion of alternative cropping systems that are suitable for the smallholder farming sector.
\end{abstract}

Keywords: water-use efficiency, land tenure, policy, extension services, institutions, training

\section{INTRODUCTION}

Agriculture faces multiple challenges in the $21^{\text {st }}$ century: it has to produce more food and fibre to feed a growing population with a smaller rural labour force, contribute to development in agriculture-dependent developing countries, adopt more efficient and sustainable production methods and adapt to climate change (FAO, 2009a). The most recent estimates indicate that global hunger increased in 2016 and the number of undernourished people in the world increased to an estimated 815 million, up from 777 million in 2015 (FAO et al., 2017). The food security situation deteriorated sharply in parts of sub-Saharan Africa, South-Eastern Asia and Western Asia. Satisfying the expected food and feed demand will require a substantial increase in global food production of up to $70 \%$ by 2050 (FAO, 2009a). Irrigation remains one of the most important means of meeting the food requirements of an expanding world population, that is estimated to reach 8.5 billion by the year 2030. In projecting global water demands, Seckler et al. (1998) concluded that the increased demand for water by 2025 could be met by increasing the effectiveness of irrigation. Irrigation stabilizes food production as it provides protection against the unpredictability of rainfall. It can be an

To whom all correspondence should be addressed.

巡 +27218645211

e-mail: FanadzoM@cput.ac.za

Received 5 October 2017; accepted in revised form 12 June 2018 effective means to improve water use efficiency, especially in arid environments (Howell, 2001).

South Africa receives about half of the average global annual rainfall and is the $30^{\text {th }}$ driest country in the world in terms of available water per capita (Schreiner et al., 2010). Over $60 \%$ of the country receives less than $500 \mathrm{~mm}$ of rainfall per annum, which is theoretically the minimum required for successful dryland cropping, while $21 \%$ receives less than $200 \mathrm{~mm}$ (De Villiers et al., 2004). Although about $70 \%$ of crop production in the country is rainfed, only $35 \%$ of the country receives enough rainfall for successful rainfed (dryland) crop production (CSIR, 2010). The water deficit caused by low rainfall and high evaporative demand limits dryland crop production in most of South Africa, and irrigated agriculture is an important alternative (Van Averbeke et al., 2011). Unfortunately, most of the country's available water supply has already been allocated, with the only 'supply options' available being linked to intersectoral re-allocations. Agriculture is therefore under pressure to produce efficiently in terms of water use (CSIR, 2010).

The need to create employment and reduce poverty, particularly among rural Black people in South Africa is a topical issue on many platforms. Policy makers believe that an increase in the number of smallholder irrigation schemes (SIS) and the revitalisation of existing and abandoned schemes, can result in an increase in food output (Van Averbeke et al., 2011). The government also anticipates that the new and revitalised SIS will be able to assist in reducing the unemployment rate and poverty within the rural communities by creating approximately 300000 job opportunities by the 
year 2020. As a result, the South African Government has invested approximately 2 billion Rand, which is equivalent to approximately R40 $000 \mathrm{ha}^{-1}$, from public resources, in establishing, revitalising and rehabilitating SIS (Van Averbeke et al., 2011). However, the performance of SIS that have been set up as part of the post-apartheid land reform programme has been dismal (Umhlaba, 2010).

Assessments of smallholder irrigation indicate that many of the schemes have performed poorly (Bembridge, 2000; Machethe et al., 2004; Tlou et al., 2006; Fanadzo et al., 2010; Mnkeni et al., 2010). Major problems include infrastructure deficiencies emanating from inappropriate planning and design (Perret and Touchain, 2002), poor operational and management processes, inappropriate land tenure arrangements and lack of technical knowledge (Bembridge, 2000; Fanadzo et al., 2010). Elsewhere in the world, particularly in Asia, investment in irrigation was a key ingredient of the green revolution, which lifted large numbers of rural populations out of poverty and created conditions that were conducive for industrial and economic development (Turral et al., 2010). A similar development trajectory has been recommended for South Africa and other parts of Sub-Saharan Africa (Lipton, 1996). So far, the developmental impact of smallholder irrigation in this region has remained limited. The objectives of this review were to assess the challenges facing SIS in South Africa, and to explore opportunities for revitalising the schemes with particular focus on government policy and strategies to support the smallholder farmers.

\section{DEFINING SMALLHOLDER IRRIGATION SCHEMES IN SOUTH AFRICA}

Smallholder irrigation has been defined as the management of the supply of water to crops, which is initiated, organised and controlled by the landholder(s) (Adam and Carter, 1986). The extent of such activities does not exceed 10 ha per family and may be as little as 0.1 ha (ibid). Smallholder irrigation can be classified as either 'formal' or 'informal'. Formal irrigation systems are public or private projects that have been developed with universally accepted technical standards under state institutions and whose characteristics have been reported in national statistics (Gutiérrez-Malaxechebarría, 2013). For the purposes of this review, a smallholder irrigation scheme is defined as a formal irrigation scheme larger than
5 ha that was constructed or established in the former homelands or resource-poor areas specifically for occupation and use by Black farmers (Van Averbeke, 2012; Van Averbeke, 2008; Van Averbeke et al., 2011). A typical farmer usually has around 1.5 ha of land, while the total size of the schemes can range from 5 to more than 1000 ha (Denison and Manona, 2007a). In 2011, there were 302 smallholder irrigation schemes in South Africa with a combined command area of 47667 ha (Van Averbeke, 2012).

In South Africa, 1.3 million ha of land are under irrigation, of which 0.1 million ha is allocated to smallholder irrigation (Van Averbeke and Mohammed, 2006). Even though smallholder irrigation schemes only account for $3 \%$ of the irrigated area, the schemes remain important to government because of their location in the rural areas (Sinyolo et al., 2014) and their potential to uplift rural livelihoods. Table 1 shows the distribution and operational status of smallholder irrigation schemes by province in South Africa in 2011.

The design of many of the large smallholder schemes was characterised by functional diversification and centralisation of scheme management, whereby the schemes were meant to perform three functions: a commercial function, a commercial smallholder development function and a subsistence function (Van Averbeke, 2012). To perform the commercial function, a substantial part of the scheme area was allocated to a central unit that was farmed as an estate. The commercial smallholder development function was implemented by allocating a limited number of 'mini-farms' ranging between 5 ha and 12 ha in size (Van Averbeke et al., 1998) to selected African homesteads, who were judged to have the aptitude to make a success of smallscale commercial agriculture (Van Averbeke, 2012).

The current era in smallholder irrigation development in South Africa is known as 'irrigation management transfer (IMT) and revitalisation'. IMT refers to the transfer of responsibility for the management of irrigation schemes from government agencies to farmers or other local nongovernmental organisations. In South Africa, the effects of IMT have been most strongly felt on the large, modern smallholder irrigation schemes, because these projects were the most complex to manage (Van Averbeke, 2012). Since the late 1990s, the South African Government has implemented a nationwide programme to revitalise state-owned SIS. Research seems to justify further investment in existing schemes rather than the construction of new schemes (Denison and 2007b).

\section{TABLE 1}

Operational status of South African smallholder irrigation schemes by province and irrigation system (Source: Van Averbeke et al., 2011)

\begin{tabular}{|c|c|c|c|c|c|c|c|c|c|}
\hline \multirow[b]{2}{*}{ Province } & \multicolumn{4}{|c|}{ Number of operational schemes by irrigation system } & \multicolumn{4}{|c|}{ Number of non-operational schemes by irrigation system } & \multirow[b]{2}{*}{ Total } \\
\hline & $\begin{array}{c}\text { Gravity-fed } \\
\text { surface } \\
\end{array}$ & $\begin{array}{c}\text { Pumped } \\
\text { surface }\end{array}$ & Overhead & Micro & $\begin{array}{l}\text { Gravity-fed } \\
\text { surface }\end{array}$ & $\begin{array}{c}\text { Pumped } \\
\text { surface }\end{array}$ & Overhead & Micro & \\
\hline Limpopo & 49 & 9 & 30 & 13 & 12 & 5 & 41 & 11 & 170 \\
\hline Mpumalanga & 3 & 0 & 4 & 0 & 1 & 0 & 11 & 0 & 9 \\
\hline North West & 0 & 2 & 0 & 0 & 0 & 0 & 0 & 0 & 2 \\
\hline KwaZulu-Natal & 5 & 0 & 30 & 0 & 0 & 0 & 0 & 0 & 35 \\
\hline Free State & 0 & 1 & 0 & 0 & 1 & 0 & 0 & 0 & 2 \\
\hline Northern Cape & 0 & 2 & 0 & 0 & 0 & 1 & 0 & 0 & 3 \\
\hline Eastern Cape & 4 & 0 & 46 & 1 & 0 & 0 & 16 & 0 & 67 \\
\hline Western Cape & 6 & 0 & 1 & 0 & 0 & 0 & 1 & 0 & 8 \\
\hline Total & 67 & 14 & 111 & 14 & 14 & 6 & 59 & 11 & $296 \#$ \\
\hline
\end{tabular}

\#The operational status of 6 schemes, 5 in the Eastern Cape and 1 in KwaZulu-Natal, was not known, bringing the total to 302 
Denison and Manona (2007b p. 4) define revitalisation of irrigation schemes as:

a global trend that is rooted in a holistic development philosophy that is argued to result in more successful outcomes than simply repairing infrastructure. The concept of revitalisation is broad in its development focus and carries with it the expectation of re-building socially uplifting, profitable agri-business on existing schemes and in the communities surrounding schemes. Human capital development both individually and organisationally, empowerment, access to information, marketing and business strategy development are emphasised alongside repair and re-design of existing infrastructure.

Most revitalisation efforts in South Africa to date have seen little return, or worse, have resulted in perverse development outcomes (Van Averbeke et al., 2011).

\section{CHALLENGES FACING THE REVITALISATION OF SMALLHOLDER IRRIGATION SCHEMES}

\section{Inadequate funding from the government}

Smallholder farmers in South Africa have been subject to years of official neglect, despite numerous policies and programmes that proclaim the opposite (Hall and Aliber, 2010). Greenberg (2010) argues that deep cuts in the budget for agriculture implies that the sector was not high on the list of priorities for post-apartheid government. Though the budget was revised upwards from around 2003, the 2010 to 2016 budget estimates, averaging $1.78 \%$, are still below those of the 1980s in real terms. Not only is agriculture receiving less money than it did in the past, but its share as a percentage of the overall national budget has declined. The total budget allocated to agriculture has actually decreased from $2.08 \%$ in 2012 to $1.81 \%$ in 2016 . The allocation was not solely for agricultural development, but included sectors such as hunting, fishing, forestry, and rural development, meaning that the allocation specifically for agriculture is actually lower. The 2012 plateau occurred at the same time as an apparent policy shift towards rural development, and begs the question of how the additional work will be resourced (Greenberg, 2010).

Although there has been a renewed emphasis on empowering the smallholder sector for rural development, there is insufficient financial support to the agricultural sector as a whole, which means that agricultural plans cannot be carried out. The response of the national government, at a time of economic contraction, has been to reallocate resources from agriculture to other priority areas of the economy (Greenberg, 2010). Because of the perceived potential of SIS to make a substantial contribution towards national development, these projects attract substantial government investment (from the agricultural sector allocation) on an annual basis. However, the financial support currently rendered to smallholder farmers is inconsistent with the visions expressed in policy statements (Greenberg, 2010). Despite clear evidence showing that budget allocations for training, management and institutional development need to be $40-50 \%$ of the total intervention budget (Denison and Manona, 2007a), the core focus of the government has largely been on rehabilitation of irrigation infrastructure.

\section{Impact of agricultural policy and support programmes}

After 1994, the South African Government introduced programmes which were meant to address the injustices of the past, and agriculture was targeted as one of the industries that needed to be transformed. This was to be done through land reform and revitalisation of smallholder irrigation schemes (RESIS) programmes, and also providing post-settlement support to the beneficiaries of the programmes (Xaba and Dlamini, 2015). The Comprehensive Agricultural Support Programme (CASP), which came into effect in 2004, provided emerging farmers with funding for the necessary support to improve production, alleviate poverty and create jobs. While clearly not the only or largest form of agricultural support, it was the most significant capital budget line potentially available to smallholder farmers (Hall and Aliber, 2010).

CASP identified 6 areas of intervention, namely, advisory and regulatory services, capacity building, information and training, market development and financial services. The first review of CASP, conducted nationally in 2007, concluded that, contrary to its name, CASP was not comprehensive either in its reach nor in the types of support provided (Hall and Aliber, 2010). Despite having 6 focus areas, support was almost entirely restricted to on-farm infrastructure, with other components not adequately explained to farmers (Hall and Aliber, 2010; Xaba and Dlamini, 2015). For instance, from the total budget allocated to CASP, only $10 \%$ was allocated to training and capacity building (DAFF, 2007).

The beneficiaries that received the CASP support in 2009 accounted for less than $1 \%$ of smallholder farmers, suggesting that the bulk of state funding for smallholder farmers went to less than $0.02 \%$ of the intended beneficiaries (Hall and Aliber, 2010). There is some state sponsorship of large-scale processing, where this is seen as potentially strategic, but limited support exists for small-scale, localised storage and processing facilities (Greenberg, 2010). The three major factors that contributed to the exclusion of communal areas from CASP funding were the equating of CASP with 'infrastructure', the lack of secure tenure in communal areas on which to build the infrastructure, and the political priority attached to improving the perceived performance of land reform projects (Hall and Aliber, 2010). Instead, 'food security' funds were channelled, to provide 'starter packs' of seed and implements (Hall and Aliber, 2010), the sustainability of which is questionable.

Similarly, implementers in the Eastern Cape are concerned that most smallholder farmers cannot access CASP support because of the priority placed on land reform (i.e. projects outside the communal areas) and on fixed infrastructure, which requires that the beneficiary own the land in question (Hall and Aliber, 2010). The bulk of funds go to a relatively small number of land reform beneficiaries on commercial farms, yet in the Eastern Cape, agricultural officials argue that the priority should be fencing and water systems in the former Transkei. On the other hand, the fact that CASP is dependent on extension services, and yet extension services reach a negligible proportion of smallholder farmers, means that CASP is almost structurally unable to reach large numbers of intended beneficiaries (Hall and Aliber, 2010).

An impact assessment done in the Limpopo Province showed that the income for CASP beneficiaries was higher before training and decreased by $75 \%$ after they received training (Xaba and Dlamini, 2015). This is counter intuitive, as training would be expected to increase management and related skills and therefore the performance of the projects. 
Similarly, Jacobs et al. (2010) reported that the majority of the provinces that benefited through CASP had not improved in terms of productivity. An impact assessment of CASP in the Free State showed that only 1 out of 5 projects were successful and sustainable (Idsardi et al., 2008).

\section{Inadequacy of extension support services}

Capacity building is one of the missing links in smallholder irrigation development and many failures of SIS have been attributed to lack of adequately trained farmers and extension staff. Smallholder farmers generally lack technical expertise in irrigated crop management. Training is probably one of the most important requirements for successful development and management of smallholder irrigation schemes in South Africa. Training of farmers and their collectives is needed in the domains of farm and scheme management (Van Averbeke et al., 2011). The provision of support with the development of reliable networks for the marketing of produce beyond the local environs is also critical (Magingxa et al., 2009). Even in areas for which appropriate modern technologies exist, the technologies do not always reach smallholder farmers because of poor extension services and inadequate use of communication and dissemination tools (Audinet and Haralambous, 2005). South Africa's public extension service has been in gradual decline over the past years. This decline is in terms of both quality and quantity of the extension officers. The extension officers that remain are poorly trained, and the type of service provided is still the top-down, one-way provision of often inappropriate information (Greenberg, 2010).

More often than not, extension officers are not adapting to technological changes in order to effectively impart training to farmers (Xaba and Dlamini, 2015).

In 2008, there were 2152 agricultural extension officers in South Africa and almost $60 \%$ of these were located in the Eastern Cape and Limpopo provinces (Mankazana, 2008). In 2013, the total number of extension officers was reported to be slightly higher at 2210 , of whom only $9.2 \%$ had a BSc. Agriculture degree while $6.3 \%$ had an honours or higher qualification in extension (Koch and Terblanché, 2013). The ratio of extension officers to farmers is $1: 878$, which is comparable with other countries with similar agricultural issues, such as India (1:1000), Zambia (1:800) and Zimbabwe (1:700) (Department of Agriculture, 2005). The Department of Agriculture (now Department of Agriculture, Forestry and Fisheries [DAFF]) felt that the size of the workforce was less of an issue than the education and training of extension staff (Department of Agriculture, 2005). A key issue is the value attached to providing appropriate extension services to resource-poor farmers. Consideration of the potential role of community-based extension workers as auxiliaries located in the communities can be considered as a cost-effective way of producing an accountable service (Greenberg, 2010).

The Government's strategic plan for 2009-2014 indicated that dedicated resources would be set aside to recapitalise agricultural training colleges (Greenberg, 2010). DAFF has launched an Extension Recovery Plan to revive public extension services through increasing numbers, further training and reorientation of extension personnel. However, although a total of 1721 staff members were identified for skills upgrading, just 123 enrolled in 2008/09 (Mankazana, 2008). Recent statistics on the number of smallholder farmers benefiting from agricultural extension are not available. The best indicator on offer is from
Stats SA's 1997 rural survey, which found that, among those engaged in farming in the former homelands, only $11 \% \mathrm{had}$ had contact with an extension officer in the previous 12 months (Stats SA, 1999). Given that the total number of extension officers in the country now is not very different to what it was then, it is anticipated that the share of smallholder farming households receiving attention from extension staff is not very different today (Hall and Aliber, 2010). Also, extension already accounts for not less than $50 \%$ of provincial expenditure, and the important questions to ask are: 'How much larger would the extension service have to be to make an appreciable difference in reaching a significant number of Black farmers?' and 'What would be the budget implications of a significantly larger and better extension service?' (Hall and Aliber, 2010). Revitalisation of extension is a prerequisite for increased agricultural production because, even where techniques and technologies are relevant and available, smallholder farmers often have no access to them. Because agricultural technologies are rapidly changing, farmers need to be informed on how to use appropriate management practices which are applicable and affordable in their contexts.

\section{Weak institutions and organisational structures}

While material investment is essential, most of the key issues confronting the rural poor are mediated by relations with others. Consequently, a critical element for sustainable poverty reduction is institutional and organisational capacity-building among the poor themselves (Audinet and Haralambous, 2005). Resource-poor farmers must be empowered to respond to the challenges they face. A former President of the International Commission for Irrigation and Drainage (ICID), John Hennessy, in a keynote address in 1992 (Kirpich et al., 1999) said: 'Irrigation schemes in many parts of the world are known to be performing well below their full potential... There is now wide recognition that deficiencies in management and related institutional problems, rather than the technology of irrigation, were the chief constraints of poor performance of irrigation systems.'

Institutions can be defined as sets of common habits, routines, established practices, rules, or laws that regulate the relations and interactions between individuals and groups (Edquist and Johnson, 1997). Farmers on irrigation schemes are dependent on each other because they share the water distribution system. This interdependence requires a willingness on the side of farmers to work collectively in order to achieve their individual objectives (Van Averbeke et al., 2011), while at the same time also sustain the collective. Rules to govern collaboration (institutions) and structures to enforce these rules (organisations) are necessary for effective and sustainable functioning of collection action. More often than not, irrigator communities and their volunteer leadership structures find it difficult to enforce rules (Van Averbeke et al., 2011). Farmers pursuing individual instead of collective goals challenge institutions and erode organisations of irrigator communities (Letsoalo and Van Averbeke, 2006). A study of two SIS, one in the Eastern Cape and the other in KwaZulu-Natal, by Mnkeni et al. (2010) revealed that farmer organisations were largely ineffective and failed to effectively discharge their responsibilities, which negatively affected productivity and overall performance of the schemes. Therefore, any revitalisation of such schemes would hinge first and foremost on the strengthening of farmer institutions and organisations. 


\section{Land tenure arrangements}

Many studies on South African SIS have singled out land tenure as a major institutional challenge leading to poor performance (e.g. Tlou et al., 2006; Denison and Manona, 2007a, b; Fanadzo, 2010; Fanadzo et al., 2010; Mnkeni et al., 2010, Van Averbeke et al., 2011). Tenure security is very important because tenure insecurity discourages land transactions that make it possible for successful farmers to increase their land sizes. Land tenure security has been defined as the individual's perception of his/ her rights to a piece of land on a continual basis, free from imposition or interference from outside sources, as well as the ability to reap the benefits of labour or capital invested in land, either in use or upon alienation (Roth and Haase, 1998). In agriculture, tenure security presents several advantages, including increased credit use through greater incentives for investment, improved creditworthiness of projects, and enhanced collateral value of land (Roth and Haase, 1998). Clearer definition and protection of rights that comes with secure tenure reduces the incidence of disputes and raises productivity through increased agricultural investment and an increased demand for complementary short-term inputs (Roth and Haase, 1998).

Poorly-functioning land exchange markets, particularly for land rentals, appear to be one of the reasons why irrigated land in South Africa is not cropped to the optimum (Bembridge, 2000). Inadequacies in tenure security, or at least the perceptions of such inadequacies among landholders, has been identified as one of the reasons for poor performance of many SIS in South Africa (Tlou et al., 2006; Denson and Manona, 2007a, b; Mnkeni et al., 2010). Farmers on quitrent (pay rent to magistrate) and right to occupy (communal under traditional leadership) land tenure arrangements have no sense of ownership and hardly invest in new technologies.

In the Eastern Cape, some landowners noted successful production by farmers renting from them and cancelled leases. Worse still, some landlords did not feel secure enough to lease land in fear of losing it and preferred to take it out of production, resulting in large tracts of land lying fallow (Mnkeni et al., 2010). This created uncertainty as to future prospects of young farmers who would have committed resources to make a living from the practice of irrigation. Uncertainty in land tenure is a negative factor in fostering farmer investment in SIS in terms of infrastructure, skills and farmer organisation.

From a legal perspective, tenure on SIS is very ambiguous because much of the legislation that applied when the plots were first allocated has since been revoked (Manona et al., 2010). Land tenure is certainly an important factor to consider in analysing issues of successful operation and maintenance of SIS. As far as can be established, there is currently no law that provides security of tenure rights to land for rural dwellers in South Africa (Kepe and Tessaro, 2014), leading some to argue that more than 20 years since the advent of democracy, rural areas are yet to be transformed (Claassens, 2013). There is a need to develop policy on land tenure that would favour those interested and capable of farming so as to improve on productivity and hence scheme performance.

Assessments of SIS in South Africa invariably identified land tenure to be an important factor determining success or failure. Poorly functioning land-exchange markets prevented plot-holders from adapting the size of their farm enterprises to their capacity to produce, resulting in the coexistence of demand for land and land surplus (Van Averbeke, 2008).
Several studies indicated that men were the holders of plots, whilst women were doing the farming (Machethe et al., 2004; Tlou et al., 2006). The tenure system that applies to nearly all schemes precludes farmers from using their holding as collateral to access loans from registered financial service providers (Crosby et al., 2000; Machethe et al., 2004; Tlou et al., 2006). Tlou et al. (2006) identified tenure as the system that had the greatest overall impact on other systems relevant to irrigation farming. Many plot-holders feel insecure about renting land, because there is no legal protection against owners claiming back their plots before the lease arrangement had expired (Van Averbeke, 2008). Manona et al. (2010) argued that the development of scheme-based land-administration systems could remove most of the uncertainties surrounding land rights and lease contracts.

\section{Low cropping intensity}

Land-use, as expressed in terms of the number of crops that are cultivated on a particular surface area per year, is termed cropping intensity. Under irrigated conditions in most parts of South Africa, it is possible to grow 2 crops per year, which would translate into a cropping intensity of $200 \%$ (van Averbeke et al., 1998). However, average cropping intensities of $48 \%$ were reported in the Eastern Cape (Fanadzo et al., 2010). In this province, cropping intensity was related to plot size, with higher intensities at smaller plots than at plots larger than 1 ha. This implies that larger plots are too labour intensive and expensive to handle within the constraints of the smallholder farmers' current farming system, as noted earlier in this review. In KwaZulu-Natal, approximately $75 \%$ of the area of the irrigation schemes was not being utilised due to lack of motivation and resources (Bembridge, 2000), while in the Limpopo Province only about $15 \%$ of the Arabie-Olifants River irrigation scheme was cultivated (Mphahlele et al., 2000). Also in Limpopo, $42 \%$ of Thabina irrigation scheme was unused because the plot holders were not interested in farming (Perret et al., 2003). These results show that the land is not used as intensively as it could be on SIS.

\section{Diversity among schemes}

Rural transformation demands a location-specific combination of investment and policy support (Audinet and Haralambous, 2005). Irrigation schemes are highly case-specific, potentially complex, dynamic, socio-biophysical entities (Lankford and Gillingham, 2001). The heterogeneity of SIS arises from many factors, such as farmer objectives and natural resource base, technology, scheme and plot size, farmer profile and marketing opportunities (Bembridge, 2000; Perret and Touchain, 2002; Lankford, 2004; Bolding, 2004). This diversity means that different kinds of interventions are needed to respond to varying farmers' needs, resources and agricultural contexts (Van Averbeke et al., 2011). A lack of appreciation of the diversity of SIS is what has led to the Government's core focus on rehabilitation, with the concomitant result of repeated failure of state-funded interventions to achieve farmer development objectives.

\section{Lack of interest in farming}

The lack of interest in farming among young rural people is a risk to consider when it comes to South Africa's smallholder agricultural sector. The dominance of old-aged farmers raises 
critical questions about the future of irrigation farming (Kamara et al., 2002). The situation whereby women are the actual farmers, but title deeds are mostly in the names of men, may also be creating disincentives to farming (Kamara et al., 2002). The level of education, which may be related to knowledge in farming, as well as farming experience, have positive effects on plot-level performance. It is extremely important to assess the number and types of people genuinely interested in farming on the schemes, and to distinguish them from those who are just 'passing the time' or mere pretenders who have other more reliable income sources, but perhaps wanting to capture rents from development assistance by being part of the irrigation management and transfer (IMT) process (Kamara et al., 2002).

\section{Market constraints}

An obvious disincentive for a move towards intensification of irrigation schemes is limited access to market infrastructure. In many cases, the irrigation schemes are located in remote areas where road infrastructure is underdeveloped, links to markets are limited and the value chain actors are non-existent (Amede, 2015). More often than not, SIS are not accessible during the rainy season, thereby restricting farmers' access to production inputs, and creating difficulty in transporting produce to the markets. The production of the same crops at the same time with limited numbers of consumers and traders results in the saturation of markets, resulting in losses. Similarly, the tendency of the same agricultural and extension packages being promoted at multiple sites, and extension usually focused solely on crop production, is not benefiting the smallholder irrigation sector. Involvement of agribusinesses and processers who could facilitate the value chain and reduce farm losses (Amede, 2015) should form part of the intervention package in revitalising SIS.

The lack of market connectivity and adequate storage facilities results in local price slumps at harvest time, when many of the poorest households are most in need of income (Burney and Naylor, 2012). Poussin et al. (2015) noted inadequate market access as the major constraint to the performance of SIS. Most farmers rely on buyers or hawkers who come to buy produce from the field. There is limited market incentive to encourage farm-level investments. One challenge facing high-value horticultural crop producers is the existence of a sophisticated logistical chain between the producer and the end consumer. This means that the producers have to be successful at both the sophisticated crop production process as well as at contracting with agribusiness that controls the marketing of the high-value food chain (Denison and Manona, 2007a). This is a serious challenge given South Africa's historical legacy which tends to exclude smallholder farmers from these networks and which is made more severe given a global market environment (Backeberg, 2006).

Market access can be considered in three dimensions: physical access to markets (e.g. distances, costs); structure of the markets (asymmetry of relations between farmers, market intermediaries and consumers); and producers' level of skills, information and organisation (e.g. understanding of the market, prices, bargaining) (IFAD, 2003). From this perspective, the integration process of the emerging farmers should not be viewed in a narrow context of only allocating land and water, but in a broader perspective that embeds the access to these resources in an overall economic framework that include access to markets, credit and extension (Magingxa and Kamara, 2003).

\section{Water rights}

Water rights are currently receiving increased attention from scholars and policymakers due to the growing understanding that ill-defined water rights impair efficient use of water. In South Africa, smallholder irrigation faces problems of low water-use efficiency and cost recovery of government investments. Research results indicate that smallholders are prepared to pay considerably higher water prices if these are connected to improvements in the water rights system (Speelman et al., 2010) and they are assured of reliable access to water for irrigation and other productive uses. Lack of clear and effective water rights systems creates major problems for the management of irrigation water (Bruns et al., 2005; MeinzenDick and Nkonya, 2005), simply because ill-defined property rights limit the value people assign to a resource (Heltberg, 2002; Halsema and Withagen, 2008; Libecap, 2009).

Ill-defined water rights create high transaction costs for making decisions over water use, which adversely affects wateruse efficiency (Wichelns, 2004). With secure and well-defined water rights, the users are willing to pay higher prices for water use because the transaction costs can be reduced (Herrera et al, 2004). Improved water rights are expected to motivate smallholder farmers to use water more productively and invest in water-conserving technologies (Wichelns, 2004; Bruns, 2007; Brooks and Harris, 2008). Increased willingness to pay for water as a result of secure and well-defined water rights can allow governments to improve cost recovery (Ntengwe, 2004; Virjee and Gaskin, 2005). Both these aspects are of relevance as the smallholder irrigation sector in South Africa is inefficient in its use of water (Speelman et al., 2008) and the level of cost recovery of government investments is considered insufficient (Backeberg, 2006; Speelman et al., 2010).

\section{OPPORTUNITIES FOR REVITALISING SMALLHOLDER IRRIGATION SCHEMES IN SOUTH AFRICA}

\section{Partnership with agri-business}

Smallholder farmers are motivated by the certainty of market access, reduction in price uncertainty, better access to inputs and reduced input costs, and access to information and technology, especially for new high-value crops (Al-Hassan et al., 2006). On the other hand, the principal motivation of agribusiness is assured supplies of produce and regularity of supplies. Smallholder and agribusiness linkages are therefore vertical integrations aimed at meeting the constraints of either party, by providing market guarantees to the farmers and assuring supply to the purchasers. The incentives brought about by better market access can result in expanded production and the accompanying adoption of productivity-enhancing technologies (Al-Hassan et al., 2006). Linkage to agribusiness is even more desirable for production of high-value crops because the production systems are more costly, the production risks are higher than they are with traditional staple foods, and the information needs and skills requirements of high-value crops are more demanding (Al-Hassan et al., 2006).

The World Bank has promoted contract farming as a way of creating dynamic partnerships between private capital and smallholders, which would lead to technology transfer, innovation and market growth (World Bank, 2005). Literature on SIS in South Africa indicates that the few exceptions to the general poor performance include the smallholder sugarcane farms in KwaZulu-Natal and Mpumalanga (Bembridge, 2000). 
This success has been linked to partnership with agribusiness (Al-Hassan et al., 2006). The link of smallholders to the sugar company has improved livelihoods and alleviated poverty in many households in the communities.

Many SIS farmers have been involved in unsuccessful contract farming in the past. The weakest point in the past contracts is that there has been no capacity building in terms of farmer training and monitoring in crop production management, leading to poor quality and low quantity produce. Smallholders need markets, but they often need seasonal capital and inputs to enhance productivity. Enhanced capacity of smallholders to meet international standards (of production methods and the quality of produce) is often the beginning of a fruitful engagement in profitable value chain systems (Al-Hassan et al., 2006). However, recent research shows that many of the South African rivers from which water is drawn for agricultural irrigation purposes are carrying extraordinarily high pathogen loads (Sigge and Lamprecht, 2016). The deteriorating quality of irrigation water may become a major hurdle for smallholder farmers who do not have the economy of scale to treat water to meet international water quality standards and penetrate large chains. Also, high-value fresh fruit and vegetable crops are often minimally processed and the products are eaten raw; the higher the value of the crop, the lower the acceptance threshold for contamination. It is easier for a large chain to monitor the quality from a relatively small number of large suppliers than from hundreds of individual suppliers. Imposing penalties on large suppliers for inferior or contaminated produce may arguably also be easier.

Farmer organisations are seen as an instrument for farmers to enhance their market power by providing training and extension, and facilitating acquisition of technology and other inputs. Such an organised body is expected to be a channel through which agribusiness might influence practices of individual members to achieve the quality requirements of the former. This emphasises the need for institutional and organisational strengthening if smallholder farmers are to partner with the private sector successfully.

\section{Increasing crop yields}

There are still ample opportunities to increase water-use efficiency in smallholder farming, and the opportunity to raise crop yields with the existing technologies seems considerable (FAO, 2009b). Provided the appropriate socio-economic incentives are in place, there are still ample 'bridgeable' gaps in yield that could be exploited (FAO, 2009b). In Africa where most crops have not yet reached 70 to $80 \%$ of their biological yield potential, public investment in research, education, and extension can result in sizeable improvements (Lobell et al., 2009). Empowering smallholder farmers to increase yields will be the most important strategy to meet growing demand. Increasing yields is particularly important to South African smallholder farmers where the gap between current and potential yields is large (Fanadzo et al., 2010).

\section{Production of high-value crops}

Horticulture is presented by some as an answer to the challenge of achieving high returns from small plot sizes (Van Averbeke et al., 2011). Diversification into high-value crops may be particularly important for poverty alleviation given the evidence of declining per capita land holdings across the continent (Jayne et al., 2003; Nagayets, 2005). Although family labour can be successfully deployed for the production of high-value crops on small plots (Feder, 1985; Collins, 1995), smallholder farmers require the same access to supply services, processing facilities and product markets as their large-scale commercial counterparts (Conradie et al., 1996). This has rarely been the case in South Africa (Van Averbeke et al., 2011), where the increasingly sophisticated value chains that link large-scale producers to the four major supermarket chains pose a major challenge to smallholders (Ramabulana, 2011).

The high costs on technically complex schemes and the inability for engagement with higher-value crop mixes and value chains has led to land consolidation into larger farms, with farming activities being carried out by a few skilled and well-resourced individuals (Van Averbeke et al., 2011). This has resulted in state-driven initiatives, where all plots are consolidated into a single landholding entity and then 'leased' with infrastructure to a commercial partner. Regrettably, the partner typically farms independently or in a nominal partnership with land-right holders, involving their employment (Van Averbeke et al., 2011). This enterprise model should only be considered as a last resort for highly complex schemes where infrastructure is still functional but the level of complexity has halted farming (Van Averbeke et al., 2011). The model should not be an option for new schemes or for conversion of existing schemes as part of revitalisation (Crosby et al., 2000; Laker, 2004). Regrettably, this model has been imposed on several scheme communities during the RECHARGE phase of the Limpopo revitalisation of smallholder irrigation schemes (RESIS) programme and is also being used in revitalisation of dryland farming in KwaZuluNatal and the Eastern Cape (Umhlaba, 2010). There is a need to find a balance between these large schemes and the degree of food security they bring to feed megacities, and the desperately needed development of small units that will contribute in various ways to socio-economic development, social cohesion, and food security in rural areas.

\section{Increase water use efficiency}

Irrigation uses more than $60 \%$ of all water in South Africa and about $60 \%$ of irrigation water applied globally does not reach the targeted crops. Although low irrigation and wateruse efficiencies are disappointing, the fact that they are so low provides plenty of scope for improvement and ultimately the hope that it will be possible to grow more food with existing water resources (Wallace, 2000). There are a wide range of options available for improving irrigation efficiency at the field level (Table 2). Attempts to improve the efficiency of irrigation that are centred solely on a technological, agronomic or institutional quick fix are rarely successful (Wallace and Batchelor, 1997).

It is possible to increase water-use efficiency by $25-40 \%$ through modifying practices that involve tillage and by $15-25 \%$ through nutrient management in soils (Hatfield et al., 2001). The potential for improving water-use efficiency in smallholder irrigated agriculture is therefore substantial. However, smallholder farmers do not have the financial resources to test and implement technologies that maximise water-use efficiency. This makes extension and government-funded research and development programmes essential. The present cost of water to the farmer in several irrigated regions is usually too low to have a real impact on demand or to bring supply and demand into balance (Qadir et al., 2003). The low cost of water to the farmer partly explains the mismanagement of available 
TABLE 2

Examples of options available for improving irrigation efficiency at the field level (Source: Adapted from Wallace and Batchelor,1997; third column added by authors)

\begin{tabular}{|c|c|c|}
\hline Improvement category & Options & Application to smallholder irrigation schemes: examples \\
\hline Agronomic & $\begin{array}{l}\text { Improved crop husbandry; introduction of higher- } \\
\text { yielding varieties; adoption of cropping strategies } \\
\text { that maximize cropped area during periods of low } \\
\text { potential evaporation and periods of high rainfall; } \\
\text { application of affordable low rates of fertilizer and } \\
\text { other organic sources of nutrients to increase cereal } \\
\text { yields; benefits of legume-cereal rotations }\end{array}$ & $\begin{array}{l}\text { New maize cultivars produced 55\% more grain yield in } \\
\text { small irrigation schemes (Fanadzo et al., 2009). Weed } \\
\text { management and plant stand were identified as the } \\
\text { most important determinants of maize grain yield, } \\
\text { while nitrogen management was the most important } \\
\text { determinant of green maize productivity (Fanadzo et } \\
\text { al., 2010). Low rates of nitrogen fertilizer in combination } \\
\text { with manure (Ncube et al., 2007a), and micro-dosing with } \\
\text { nitrogen fertiliser (Twomlow et al., 2010) increased cereal } \\
\text { yields in smallholder farms. Legume-cereal rotations } \\
\text { resulted in increased cereal yields when grown after } \\
\text { legumes (Ncube et al., 2007b). }\end{array}$ \\
\hline Technical & $\begin{array}{l}\text { Laser levelling of flood irrigation schemes to } \\
\text { improve water distribution uniformity; adoption } \\
\text { of cropping practices that can enhance rainfall } \\
\text { capture; introduction of more efficient irrigation } \\
\text { methods (e.g. drip irrigation and subsurface } \\
\text { irrigation) that reduce soil evaporation, improve } \\
\text { uniformity and reduce drainage }\end{array}$ & $\begin{array}{l}\text { New low-cost technologies that are being developed to } \\
\text { improve water-use efficiency in small irrigation schemes, } \\
\text { such as the use of the Chameleon and Wetting Front } \\
\text { Detectors (Stirzaker et al., 2014), which improve water } \\
\text { savings, reduce labour and increase crop production. A } \\
\text { change from conventional to conservation agriculture } \\
\text { can increase crop productivity by } 20-120 \% \text { and water } \\
\text { productivity by } 10-40 \% \text { (Rockstrom et al., 2010; } \\
\text { Nyamangara et al., 2014; Thierfelder et al., 2015) }\end{array}$ \\
\hline Managerial & $\begin{array}{l}\text { Adoption of demand-based irrigation scheduling; } \\
\text { use of slight to moderate deficit irrigation to } \\
\text { promote deeper soil water extraction; avoiding } \\
\text { root zone salinity yield thresholds; improved } \\
\text { maintenance of irrigation equipment to reduce } \\
\text { unexpected failures }\end{array}$ & $\begin{array}{l}\text { Poor management was cited as the most frequent cause } \\
\text { of inefficient water use on irrigation schemes (Jensen et } \\
\text { al., 1990). Low water productivity was attributed to weak } \\
\text { infield water management at scheme level (Fanadzo et } \\
\text { al., 2010). Farmers did not exercise objective scheduling } \\
\text { methods and tended to apply the same amount of water } \\
\text { regardless of crop type and growth stage (Machethe et } \\
\text { al, 2004; Fanadzo et al., 2010). Relatively higher yields } \\
\text { at some irrigation schemes were attributed to better } \\
\text { irrigation facilities and consistency in water application } \\
\text { to the crops throughout the growing season (Machethe et } \\
\text { al., 2004). }\end{array}$ \\
\hline Institutional & $\begin{array}{l}\text { User involvement in scheme operation and } \\
\text { maintenance; introduction of water pricing and } \\
\text { legal frameworks to provide incentives for efficient } \\
\text { water use and disincentives for inefficient use; } \\
\text { introduction of integrated catchment management; } \\
\text { improved training and extension }\end{array}$ & $\begin{array}{l}\text { Farmers doubled rice productivity and increased } \\
\text { their net incomes by } 230 \% \text { due to higher yields, both } \\
\text { quantity and quality after receiving basic training on } \\
\text { crop production (List, 2009). Training resulted in yield } \\
\text { increases of } 100 \% \text { for rye grass, } 67 \% \text { for potato and } \\
27-177 \% \text { for maize (World Bank, } 2017 \text { ). After training } \\
\text { using the farmer field school, yield increase of } 43 \% \text { in } \\
\text { wheat, } 77 \% \text { in melon, } 28 \% \text { in potato and } 49 \% \text { in rice were } \\
\text { realised (FAO, 2018). }\end{array}$ \\
\hline
\end{tabular}

water resources by the smallholder producers because there is no incentive for improved water management. Shortage of water and inadequate funding for maintaining irrigation works are prevalent. In this context, use of water charges to generate resources for maintenance and to reduce demand is widely advocated (Perry, 2001).

\section{Farmer participation in planning}

One of the major problems that has led to the failure of smallholder farmer projects is the exclusion of the farmers in the planning stages of projects. It is always questionable to what extent concerned communities/groups are part of the decision-making processes that are meant to ultimately improve their livelihoods. Mollinga et al. (2007) and Hope (2006) argue that participation and livelihood analysis are key in determining and evaluating priorities for communities prior to implementing interventions, human capacity building, financial assistance, establishing institutions, and any other commitment. In the water sector, the participatory process has been adopted in order to bring about inclusion, create a sense of ownership, achieve equity, and to build a sense of trust and citizenship, which all contribute towards good governance and decentralisation of water (Cleaver and Franks, 2008). This approach can be adopted in the development and implementation of SIS with the hope of creating a sense of ownership and ultimately responsibility towards projects.

Catchment management forums and water user associations can be places for enthusiastic participation, communities of practice in the making, and be crucial to the devolution of water management to local stakeholders (Munnik et al., 2016). The role of catchment management forums is to act as a communication channel between catchment residents and local government, municipality and other 
institutions. They can also be educational bodies, watchdogs, and initiating and organisational structures for activities in various catchments within South Africa (Munnik et al., 2016). Unfortunately for water users in SIS, democratically elected representation is not fully recognized, water use is considered insignificant and a collective identity around water does not exist. Therefore, a more profound process which deals with historical inequality needs to take place without victimizing or ignoring the multiple social identities of all the actors, and taking into account the various normative orders that exist in society (Kemerink et al., 2013). For collaboration in water management, this means opening up space for bargaining not only over the content but also over the institutions that govern this collaboration. Unless this inherently political participatory process is initiated and the different institutional preferences become part of the negotiation process for the 'why' and the 'how' of progressive collaboration at catchment level, the establishment of water user associations will not contribute to achieving the transformation envisioned for rural South Africa (Kemerink et al., 2013).

There also seems to be no interaction between researchers and implementers of government policy on revitalisation of SIS in South Africa. Research findings are largely ignored, resulting in continuous poor performance despite huge investments. Despite numerous calls on the need to balance soft and hard components of the irrigation schemes, the focus of the government has continued to be on irrigation infrastructure and supply of inputs at the expense of other crucial processes such as farmer participation and empowerment.

\section{CONCLUSIONS AND RECOMMENDATIONS}

Revitalisation efforts need to develop inclusive, scheme-specific agricultural development plans, and to improve institutional mechanisms for addressing the many dimensions of policies and investment opportunities. Improvement of the productivity of smallholder irrigation schemes requires collective action and improved irrigation efficiency. Combined strategies and institutional capacity, including technical applications such as the introduction of high-yielding, water-efficient and highvalue crops, have to be part of the revitalisation intervention. Because of the diversity among schemes, situation analyses of individual SIS should be conducted in order to identify major constraints, and then address the specific problems with the participation of resident farmers. A much broader holistic strategy, which also includes institutional change along with technical interventions, is required.

Given the low skill levels of farmers and extension officers, the need to invest more resources in training programmes cannot be overemphasised. The present priority of infrastructure support over training and capacity building reverses the intended gains of the programme. The need to review the training programmes offered to both farmers and extension officers is urgent. The training provided should be focused on development of entrepreneurial skills in order to reduce the dependency syndrome among project beneficiaries. A farmer-to-farmer extension model, which identifies and uses successful farmers (master farmers) can also serve as a good strategy for training and capacity building at local level. The cluster approach, which combines farmers with similar commodities, is one option that is expected to increase the scope and efficiency of training. Commodity-based mentorship can narrow the skills gap in farming by providing business skills to the farmers, thereby reducing the dependency syndrome. Being a long-term project, a mentorship programme brings the advantage of an established relationship, with clear exit plans.

In a context of water scarcity and climate change, the maximizing of water use efficiency in SIS should be prioritized. Alternative methods of irrigation, such as drip or microirrigation, can increase efficiency and drastically reduce wastage. While there are some small-scale efforts to deal with adaptation to climate change, including water harvesting, and altering production towards more drought-tolerant crops, these efforts do not match the scale of the challenge facing agricultural producers, especially those in drier areas with limited resources of their own. There is also a need to strengthen the institutions that govern water at local level to ensure the participation of smallholder farmers.

Research has shown that infrastructure development alone as a dominant part of revitalisation is bound to fail. For success, interventions based on comprehensive strategies addressing the complexity of activities that make up the irrigation enterprise should be implemented. The Water Research Commission of South Africa has produced a wealth of information (research reports and other publications) on SIS for a number of years. This is data produced by expert researchers and the information is readily available. For the government to repeat the same mistakes while recommendations for sustainability are available is therefore inconceivable.

\section{ACKNOWLEDGEMENTS}

The authors would like to thank Dr Ernest Dube for proofreading the manuscript and for his insightful comments and recommendations. The authors also thank the anonymous reviewers, whose comments were valuable in improving this paper.

\section{REFERENCES}

ADAM WM and CARTER RC (1986) Small-scale irrigation in sub-Saharan Africa. Prog. Phys. Geogr. 11 1-27. http://dx.doi. org/10.1177/030913338701100101

AL-HASSAN RM, SARPOND DB and MENSAH-BONSU A (2006) Linking smallholders to markets. A draft report submitted to the International Food Policy Research Institute's Ghana Strategy Support Program (GSSP). Background paper number GSSP 0001.

AMEDE T (2015) Technical and institutional attributes constraining the performance of small-scale irrigation in Ethiopia. Water Resour. Rural Dev. 6 78-91. http://dx.doi.org/10.1016/j. wrr.2014.10.005

AUDINET JP and HARALAMBOUS S (2005) Achieving the Millennium Development Goals: Rural investment and enabling policy. Panel discussion paper, IFAD Governing Council - Twentyeighth session, 16-17 February 2005, Policy Division, IFAD. URL: http://www.un.org/esa/coordination/Alliance/achievingMDG.pdf (Accessed 19 May 2017).

BACKEBERG GR (2006) Reform of user charges, market pricing and management of water: problem or opportunity for irrigated agriculture. Irrig. Drain. 55 (1) 1-12. http://dx.doi.org/10.1002/ ird. 221

BEMBRIDGE TJ (2000) Guidelines for rehabilitation of small-scale farmer irrigation schemes in South Africa. WRC Report No. 891/1/00. Water Research Commission, Pretoria.

BOLDING A (2004) In hot water: A study on sociotechnical intervention models and practices of water use in smallholder agriculture, Nyanyadzi Catchment, Zimbabwe. PhD thesis, Research School for Resource Studies for Development, Wageningen University, The Netherlands. 398 pp.

BROOKS R and HARRIS E (2008) Efficiency gains from water markets: empirical analysis of Watermove in Australia. Agric. Water Manage. 95 391-399. http://dx.doi.org/10.1016/j.agwat.2007.10.020 
BRUNS B, RINGLER C and MEINZEN-DICK R (2005) Introduction. In: Bruns B, Ringler C and Meinzen-Dick R (eds) Water Rights Reform: Lessons for Institutional Design. IFPRI, Washington DC.

BRUNS B (2007) Irrigation water rights: options for pro-poor reform. Irrig. Drain. 56 237-246. http://dx.doi.org/10.1002/ird.314

BURNEY JA and NAYLOR RL (2012) Smallholder irrigation as a poverty alleviation tool in Sub-Saharan Africa. World Dev. 40 (1) 110-123. http://dx.doi.org/10.1016/j.worlddev.2011.05.007

CLAASSENS A (2013) Bantustans left untransformed. Mail \& Guardian 14 June 2013.

CLEAVER F and FRANKS T (2008) Distilling or diluting? Negotiating the water research-policy interface Water Altern. 1 (1) 157-176.

COLLINS J (1995) Farm size and non-traditional exports: Determinants of participation in world markets. World Dev. 23 (7) 1103-1114. http://dx.doi.org/10.1016/0305-750X(95)00036-C

CONRADIE B, ECKERT J, KLEYNHANS T and GRISSEL H (1996). Apple production systems by small-scale farmers in the Western Cape. Agrekon 35 (1) 1-11. https://doi.org/10.1080/03031853.1996. 9524301

CROSBY CT, DE LANGE M, STIMIE CM and VAN DER STOEP I (2000) A review of planning and design procedures applicable to small-scale farmer irrigation projects. WRC Report No. 578/2/00. Water Research Commission, Pretoria, South Africa.

CSIR (Council for Scientific and Industrial Research) (2010) A CSIR perspective on water in South Africa - 2010. CSIR Report No. CSIR/NRE/PW/IR/2011/0012/A. CSIR, Pretoria.

DAFF (Department of Agriculture, Forestry and Fisheries, South Africa) (2007) A national review of the Comprehensive Agricultural Support Programme. Department of Agriculture, Forestry and Fisheries, Pretoria.

DENISON J and MANONA S (2007a) Principles, approaches and guidelines for the participatory revitalisation of smallholder irrigation schemes. Volume 1 - A rough guide for irrigation development practitioners. WRC Report No. TT 308/07. Water Research Commission, Pretoria.

DENISON J and MANONA S (2007b) Principles, approaches and guidelines for the participatory revitalisation of smallholder irrigation scheme. Volume 2 - concepts and cases. WRC Report No. TT 308/07. Water Research Commission, Pretoria.

DEPARTMENT OF AGRICULTURE (2005) AET Strategy. National Education and Training strategy for Agricultural and Rural Development in South Africa. Directorate of Education and Training. Pretoria.

DE VILLIERS MC, ELOFF JF, BARNARD RO, MULIBANA E, MKHIZE S and MSOMI B (2004) Land and water management: South Africa situation analysis. In: Nhira C and Mapiki A (eds) Regional Situational Analysis: Land and Water Management in the SADC Region. SADC Workshop Proceedings 1. 93-112.

EDQUIST C and JOHNSON B (1997) Institutions and Organizations in Systems of Innovation, In: Edquist C (ed.) Systems of Innovation: Technologies, Institutions and Organizations. Pinter Publishers. London. 41-63.

FANADZO M (2010) Improving productivity of maize-based smallholder irrigated cropping systems, a case study of Zanyokwe irrigation scheme, Eastern Cape, South Africa. PhD thesis, University of Fort Hare, South Africa. 385 pp.

FANADZO M, CHIDUZA C and MNKENI PNS (2009) Investigation of agronomic factors constraining productivity of grain maize (Zea mays L.) at Zanyokwe irrigation scheme, Eastern Cape, South Africa. J. Appl. Biosci. 17 948-958.

FANADZO M, CHIDUZA C, MNKENI PNS, VAN DER STOEP I and STEVENS J (2010) Crop production management practices as a cause for low water productivity at Zanyokwe irrigation scheme. Water SA 36 (1) 27-36. http://dx.doi.org/10.4314/wsa.v36i1.50904

FAO (2018) FFS results and Farmer's Capacity Building. Integrated Pest Management (IPM) in Afghanistan. URL: http://ipm-af.org/ ffsresults/ (Accessed 16 May 2018).

FAO (2009a) How to feed the world - 2050. High level expert forum, 12-13 October 2009, Rome. FAO, Rome.

FAO (2009b) Global Agriculture towards 2050. URL: http://www.fao. org/fileadmin/templates/wsfs/docs/Issues_papers/HLEF2050_ Global_Agriculture.pdf(Accessed 10 May 2017).

FAO, IFAD, UNICEF, WFP and WHO (2017) The state of food security and nutrition in the world 2017. Building resilience for peace and food security. FAO, Rome. URL: http://www.fao.org/3/a-i7695e.pdf (Accessed 16 May 2018).

FEDER G (1985) The relationship between farm size and farm productivity: The role of family labour, supervision and credit constraints. J. Dev. Econ. 18 (2-3) 297-313. https://doi. org/10.1016/0304-3878(85)90059-8

GREENBERG S (2010) PLAAS Research Report 40. Status report on land and agricultural policy in South Africa, 2010. Institute for Poverty, Land and Agrarian Studies, School of Government, University of the Western Cape, South Africa.

GUTIÉRREZ-MALAXECHEBARRÍA A (2013) Informal irrigation in the Colombian Andes: local practices, national agendas and options for innovation. Mt. Res. Dev. 33 (3) 260-268. https://doi org/10.1659/MRD-JOURNAL-D-12-00116.1

HALL R and ALIBER M (2010) The case of re-strategizing spending priorities to support small-scale farmers in South Africa. Working Paper 17. Institute for Poverty, Land and Agrarian Studies (PLAAS), University of Western Cape, Cape Town.

HALSEMA A and WITHAGEN C (2008) Managing multiple fishery pools: property rights regimes and market structures. Environ. Dev. Econ. 3 775-794. http://dx.doi.org/10.1017/S1355770X08004701

HATFIELD JL, SAUER TJ and PRUEGER JH (2001) Managing soils to achieve greater water use efficiency: a review. Agron. J. 93 271-280. http://dx.doi.org/10.2134/agronj2001.932271x

HELTBERG R (2002) Property rights and natural resource management in developing countries. J. Econ. Surv. 16 189-214. http://dx.doi.org/10.1111/1467-6419.00164

HERRERA P, VAN HUYLENBROECK G and ESPINEL R (2004) An application of the contingent valuation method to assess the efficiency of the institutional structure of irrigation property rights: the case of the Peninsula of Santa Elena. Int. J. Water Resour. Dev. 20 537-551. http://dx.doi.org/10.1080/07900620412331319171

HOPE RA (2006) Evaluating water policy scenarios against the priorities of the rural poor. World Dev. 34 (1) 167-179. http://dx.doi. org/10.1016/j.worlddev.2005.07.014

HOWELL TA (2001) Enhancing water use efficiency in irrigated agriculture. Agron. J. 93 281-289. http://dx.doi.org/10.2134/ agronj2001.932281x

IDSARDI E, JORDAAN H and VAN SCHALKWYK HD (2008) A characterisation of success factors of the projects funded by the Comprehensive Agricultural Support Programme in the Free State Province. University of the Free State, Bloemfontein.

IFAD (2003) Promoting market access for the rural poor in order to achieve the millennium development goals. Roundtable Discussion Paper for the Twenty-Fifth Anniversary Session of IFAD's Governing Council. IFAD, Rome. URL: https://www.ifad. org/documents/10180/79e82056-a4be-44d2-9362-9cc093b9176d (Accessed 10 May 2017).

JACOBS P, BAIPHETHI M, NGCOBO N and HART T (2010) The potential of social grants expenditure to promote local economic development and job creation. Centre for Poverty, Employment and Growth, Human Sciences Research Council, Pretoria.

JAYNE TS, YAMANO T, WEBER MT, TSCHIRLEY D, BENFICA R, CHAPOTO A and ZULU B (2003) Smallholder income and land distribution in Africa: implications for poverty reduction strategies. Food Polic. 28 (3) 253-275. http://dx.doi.org/10.1016/ S0306-9192(03)00046-0

JENSEN ME, RANGELEY WR and DIELEMAN PJ (1990) Irrigation trends in world Agriculture. In: Stewart BA and Nielsen DR (eds): Irrigation of Agricultural Crops. Agronomy Monograph 30. ASA, Wisconsin. 31-67.

KAMARA AB, VAN KOPPEN B and MAGINGXA L (2002) Economic viability of small scale irrigation systems in the context of state withdrawal: the Arabie Scheme in the Northern Province of South Africa. Phys. Chem. Earth 27 815-823. http://dx.doi.org/10.1016/ S1474-7065(02)00070-0

KEMERINK JS, MÉNDEZ LE, AHLERS R, WESTER P and VAN DER ZAAG P (2013) The question of inclusion and representation in rural South Africa: challenging the concept of water user associations as a vehicle for transformation. Water Polic. 15 (2) 243-257. http://dx.doi.org/10.2166/wp.2012.127

KEPE T and TESSARO D (2014) Trading off: Rural food security and

http://dx.doi.org/10.4314/wsa.v44i3.11

Available on website http://www.wrc.org.za

ISSN 1816-7950 (Online) = Water SA Vol. 44 No. 3 July 2018

Published under a Creative Commons Attribution Licence 
land rights in South Africa. Land Use Polic. 36 267-274. http:// dx.doi.org/10.1016/j.landusepol.2013.08.013

KIRPICH P, HAMAN D and STYLES S (1999) Problems of irrigation in developing countries. J. Irrig. Drain. Eng. 125 (1) 1-6. https://doi. org/10.1061/(ASCE)0733-9437(1999)125\%3A1(1)

KOCH BH and TERBLANCHÉ SE (2013) An overview of agricultural extension service in South Africa. S. Afr. J. Agric. Ext. 41 107-117.

LAKER MC (2004) Development of a general strategy for optimising the efficient use of primary water resources for effective alleviation of rural poverty. WRC Report No. KV149/04. Water Research Commission, Pretoria.

LANKFORD BA (2004) Irrigation improvement projects in Tanzania: Scale impacts and policy implications. Water Polic. 6 89-102.

LANKFORD BA and GILLINGHAM P (2001) The impacts of irrigation improvement programmes. Paper presented at the 1st National Irrigation Conference, 20-22 March, 2001, Morogoro, Tanzania.

LETSOALO SS and VAN AVERBEKE W (2006) Infrastructural maintenance on smallholder canal irrigation schemes in the north of South Africa. Proc. International Symposium on Water and Land Management for Sustainable Irrigated Agriculture, 4-8 April 2006, Cukurova University, Adana, Turkey.

LIBECAP GD (2009) The tragedy of the commons: property rights and markets as solutions to resource and environmental problems. Aust. J. Agric. Resour. Econ. 53 129-144. http://dx.doi. org/10.1111/j.1467-8489.2007.00425.x

LIPTON M (1996) Rural reforms and rural livelihoods: The context of international experience. In: Lipton M, De Klerk M and Lipton M (eds): Land, Labour and Livelihoods in Rural South Africa. One: Western Cape. Indicator Press, Durban.

LIST J (2009) Rice farmers improve yield in Nigeria. FrontLines, March 2009. Bureau for Legislative and Public Affairs. US Agency for International Development, Washington.

LOBELL DB, CASSMAN KG and FIELD CB (2009) Crop yield gaps: their importance, magnitudes, and causes. Ann. Rev. Environ. Resour. 34 179-204. http://dx.doi.org/10.1146/annurev. environ.041008.093740

MACHETHE CL, MOLLEL NM, AYISI K, MASHATOLA MB, ANIM FDK and VANASCHE F (2004) Smallholder irrigation and agricultural development in the Olifants river basin of Limpopo Province: management, transfer, productivity, profitability and food security issues. WRC Report No. 1050/1/04. Water Research Commission, Pretoria.

MANKAZANA M (2008) National extension recovery implementation plan. National Department of Agriculture, Pretoria.

MANONA S DENISON J, VAN AVERBEKE W and MASIYA T (2010) Proposed land tenure and land administration interventions to increase productivity on SIS in South Africa. Paper presented at 'Overcoming Inequality and Structural Poverty in South Africa: Towards Inclusive Growth and Development', 20-22 September 2010, Birchwood Hotel and Conference Centre, Johannesburg.

MAGINGXA LL, ALEMU ZG and VAN SCHALKWYK HD (2009) Factors influencing access to produce markets for smallholder irrigators in South Africa. Dev. S. Afr. 26 (1) 47-58. https://doi. org/10.1080/03768350802640081

MAGINGXA LL and KAMARA AB (2003) Institutional perspectives of enhancing smallholder market access in South Africa. Contributed paper presented at the $41^{\text {st }}$ Annual Conference of the Agricultural Economic Association of South Africa (AEASA), 2-3 October 2003, Pretoria.

MEINZEN-DICK R and NKONYA L (2005) Understanding legal pluralism in water rights: lessons from Africa and Asia. Paper presented at the international workshop on African Water Laws: Plural Legislative Frameworks for Rural Water Management in Africa, 26-28 January 2005, Johannesburg.

MOLLINGA P, MEINZEN-DICK R and MERREY D (2007) Politics, plurality and problemsheds: a strategic approach for reform of agricultural water resources management. Dev. Polic. Rev. 25 699-719. http://dx.doi.org/10.1111/j.1467-7679.2007.00393.x

MNKENI PNS, CHIDUZA C, MODI AT, STEVENS JB, MONDE N, VAN DER STOEP I and DLADLA R (2010) Best management practices for smallholder farming on two irrigation schemes in the Eastern Cape and Kwazulu-Natal through participatory adaptive research. WRC Report No. TT 478/10. Water Research Commission, Pretoria.

MPHAHLELE RE, MALAKALAKA TM and HEDDENDUNKHORST B (2000) Characteristics of smallholder irrigation farming in South Africa: A Case Study of the Arabie-Olifants River irrigation scheme. South Africa working paper number 3. University of the North and International Water Management Institute, South Africa.

MUNNIK V, BURT J, PRICE L, BARNES G, ASHE B and MOTLOUNG S (2016) Principled, pragmatic revitalisation of Catchment Management Forums in South Africa. WRC Project No. K5/2411. Water Research Commission, Pretoria.

NAGAYETS O (2005) Small farms: current status and key trends. Information Brief, Future of Small Farms Research Workshop, 26-29 June 2005, Wye. IFPRI, Washington.

NCUBE B, DIMES JP, TWOMLOW SJ, MUPANGWA W and GILLER KE (2007a) Raising the productivity of smallholder farms under semi-arid conditions by use of small doses of manure and nitrogen: a case of participatory research. Nutr. Cycl. Agroecosys. 77 (1) 53-67. http://dx.doi.org/10.1007/s10705-006-9045-7

NCUBE B, TWOMLOW SJ, VAN WIJK MT, DIMES JP and GILLER KE (2007) Productivity and residual benefits of grain legumes to sorghum under semi-arid conditions in southwestern Zimbabwe. Plant Soil 299 (1-2) 1-15. http://dx.doi.org/10.1007/ s11104-007-9330-5

NTENGWE FT (2004) The impact of consumer awareness of water sector issues on willingness to pay and cost recovery in Zambia. Phys. Chem. Earth 29 1301-1308. http://dx.doi.org/10.1016/j. pce.2004.09.034

NYAMANGARA J, NYENGERAI K, MASVAYA EN, TIRIVAVI R, MASHINGAIDZE N, MUPANGWA W, DIMES J, HOVE L and TWOMLOW S (2014) Effect of conservation agriculture on maize yield in the semi-arid areas of Zimbabwe. Exp. Agric. 50 (2) 159-177. https://doi.org/10.1017/S0014479713000562

PERRET S, LAVIGNE M, STIRER N, YOKWE S and DIKGALE S (2003) The Thabina irrigation scheme in a context of rehabilitation and management transfer: prospective analysis and local empowerment. Final Report. DWAF, CIRAD-IWMI-UP, Pretoria.

PERRET S and TOUCHAIN E (2002) A simulation-based approach to access the economic viability of smallholding irrigation schemes in South Africa. Research Report 02/02. CIRAD-Tera, Pretoria.

PERRY CJ (2001) Charging for irrigation water: the issues and options, with a case study from Iran. International Water Management Institute Research Report 52. IWMI, Colombo.

POUSSIN JC, RENAUDIN L, ADOGOBA D, SANON A, TAZEN F, DOGBE W, FUSILLIER J-L, BARBIER B and CECCHI P (2015) Performance of small reservoir irrigated schemes in the Upper Volta basin: Case studies in Burkina Faso and Ghana. Water Resour. Rural Dev. 6 50-65. http://dx.doi.org/10.1016/j. wrr.2015.05.001

QADIR M, BOERS THM, SCHUBERT S, GHAFOOR A and MURTAZA G (2003) Agricultural water management in water-starved countries: challenges and opportunities. Agric. Water Manage. 62 165-185. http:/dx.doi.org/10.1016/ S0378-3774(03)00146-X

RAMABULANA TR (2011) The rise of South African agribusiness: The good, the bad and the ugly. Agrekon 50 (2) 102-109. http://dx.doi. org/10.1080/03031853.2011.589984

ROCKSTROM J, KARLBERG L, WANI SP, BARRON J and HATIBU $\mathrm{N}$ (2010) Managing water in rainfed agriculture - the need for a paradigm shift. Agric. Water Manage. 97 543-550. https://doi. org/10.1016/j.agwat.2009.09.009

ROTH M and HAASE D (1998) Land tenure security and agricultural development performance in Southern Africa. Broadening access and strengthening input market systems. URL: http://pdf.usaid. gov/pdf_docs/Pnacl422.pdf (Accessed 10 May 2017).

SCHREINER B, TAPELA B and VAN KOPPEN B (2010) Water for agrarian reform and poverty eradication: Where is the leak? Conference paper presented at 'Overcoming inequality and structural poverty in South Africa: Towards inclusive growth and development', 20-22 September 2010, Johannesburg.

SECKLER D, AMARASINGHE U, MOLDEN D, DE SILVA R and BARKER R (1998) World water demand and supply, 1990 to 2025 : 
scenarios and issues. International Water Management Institute Research Report 19. IWMI, Colombo, Sri Lanka.

SIGGE GO and LAMPRECHT C (2016) Scoping study on different on-farm treatment options to reduce the high microbial contaminant loads of irrigation water to reduce the related food safety risk. WRC Report No. 2174/1/16. Water Research Commission, Pretoria.

SINYOLO S, MUDHARA M and WALE E (2014) The impact of smallholder irrigation on household welfare: The case of Tugela Ferry irrigation scheme in KwaZulu-Natal, South Africa. Water SA 40(1) 145-156. http://dx.doi.org/10.4314/wsa.v40i1.18

SPEELMAN S, D'HAESE M, BUYSSE J and D'HAESE L (2008) A measure for the efficiency of water use and its determinants, a case study of small-scale irrigation schemes in North-West Province, South Africa. Agric. Syst. 98 31-39. http://dx.doi.org/10.1016/j. agsy.2008.03.006

SPEELMAN S, FAROLFI S, FRIJA A, D'HAESE M and D'HAESE L (2010) The impact of the water rights system on smallholder irrigators' willingness to pay for water in Limpopo province, South Africa. Environ. Dev. Econ. 15 465-483. https://doi.org/10.1017/ S1355770X10000161

STIRZAKER R, CAR N and CHRISTEN E (2014) A traffic light soil water sensor for resource poor farmers: proof of concept. Final project report. Australian Centre for International Agricultural Research (ACIAR), Canberra. URL: http://aciar.gov.au/files/aciar_ traffic_light_final_report_sept_14_2_2.pdf (Accessed 9 May 2017).

STATS SA (Statistics South Africa) (1999) Rural Survey. Statistics South Africa, Pretoria. URL: http://www.statssa.gov.za/ publications/P0360/P0360June1999.pdf (Accessed 9 May 2017).

THIERFELDER C, RUSINAMHODZI L, NGWIRA AR, MUPANGWA W, NYAGUMBO I, KASSIE GT and CAIRNS JE (2015) Conservation agriculture in Southern Africa: Advances in knowledge. Renew. Agric. Food Syst. 30 (4) 328-348. https://doi. org/10.1017/S1742170513000550

TLOU T, MOSAKA D, PERRET S, MULLINS D and WILLIAMS CJ (2006) Investigation of different farm tenure systems and support structures for establishing small-scale irrigation in long term viable conditions. WRC Report No. 1353/1/06. Water Research Commission, Pretoria.

TURRAL H, SVENDSEN M and FAURÈS JM (2010) Investing in irrigation: Reviewing the past and looking to the future. Agric. Water Manage. 97 551-560. http://dx.doi.org/10.1016/j. agwat.2009.07.012

TWOMLOW S, ROHRBACH D, DIMES J, RUSIKE J, MUPANGWA W, NCUBE B, HOVE L, MOYO M, MASHINGAIDZE N and MAHPOSA P (2010) Micro-dosing as a pathway to Africa's Green Revolution: evidence from broad-scale on-farm trials. Nutr. Cycl. Agroecosys. 88 (1) 3-15. http://dx.doi.org/10.1007/ s10705-008-9200-4

UMHLABA (2010) A Review of Experiences of Establishing Emerging Farmers in South Africa: Case Lessons and Implications for Farmer
Support within Land Reform Programmes. Food and Agricultural Organization of the United Nations, Rome.

VAN AVERBEKE W (2008) Best management practices for smallscale subsistence farming on selected irrigation schemes and surrounding areas through participatory adaptive research in Limpopo Province. WRC Report No. TT 344/08. Water Research Commission, Pretoria

VAN AVERBEKE W (2012) Performance of smallholder irrigation schemes in the Vhembe District of South Africa. In: Kumar M (ed.) Problems, Perspectives and Challenges of Agricultural Water Management. InTech, Rijeka, Croatia.

VAN AVERBEKE W, DENISON J and MNKENI PNS (2011) Smallholder irrigation schemes in South Africa: A review of knowledge generated by the Water Research Commission. Water SA 37 (5) 797-808. http://dx.doi.org/10.4314/wsa.v37i5.17

VAN AVERBEKE W, M'MARETE CK, IGODAN CO and BELETE A (1998) An investigation into food plot production at irrigation schemes in central Eastern Cape. WRC Report No. 719/1/98. Water Research Commission, Pretoria.

VAN AVERBEKE W and MOHAMED SS (2006) Smallholder irrigation schemes in South Africa: past, present, and future. Paper presented at the second symposium of the SANCID: The Changing face of irrigation in South Africa, 15-17 November 2006, Mpumalanga.

VIRJEE K and GASKIN S (2005) Fuzzy cost recovery in planning for sustainable water supply systems in developing countries. Energy 30 1329-1341. http://dx.doi.org/10.1016/j.energy.2004.02.021

XABA T and DLAMINI CS (2015) The Comprehensive Agricultural Support Programme's training and capacity building: An impact analysis on income levels of emerging farmers in Limpopo Province, South Africa. Am. J. Econ. Fin. Manage. 1 (3) 153-163.

WALLACE JS (2000) Increasing agricultural water efficiency to meet future food production. Agric. Ecosyst. Environ. 82 105-119. http:// dx.doi.org/10.1016/S0167-8809(00)00220-6

WALLACE JS and BATCHELOR CH (1997) Managing water resources for crop production. Phil. Trans. R. Soc. Lond. B 352 937-947. http://dx.doi.org/10.1098/rstb.1997.0073

WICHELNS D (2004) New policies are needed to encourage improvements in irrigation management. J. Irrig. Drain. Eng. 130 366-372. http://dx.doi.org/10.1061/ (ASCE) 0733-9437(2004)130:5(366)

WORLD BANK (2005) A workshop on linking small-scale producers to markets: Old and new challenges. ARD Rural Infrastructure, Markets and Finance (RIMF) Thematic Group. URL: http:// siteresources.worldbank.org/INTRANETTRADE/Resources/ Topics/Standards/MarketLinkageWorkshopReport.pdf (Accessed 10 May 2017).

WORLD BANK (2017) Better crops with better irrigation: Boosting agricultural performance in the Peruvian Sierra. URL: http://www. worldbank.org/en/results/2017/10/30/better-crops-with-betterirrigation-boosting-agricultural-performance-in-the-peruviansierra (Accessed 16 May 2018). 